\title{
Processes affecting groundwater temperature patterns in a coastal aquifer
}

\author{
${ }^{1 *}$ M. L. Calvache; ${ }^{2}$ C. Duque; ${ }^{1} J$. M. Gomez Fontalva; ${ }^{1}$ F. Crespo \\ ${ }^{1}$ Departament of Geodynamics, University of Granada, Avda. Fuentenueva, 18071 Granada, Spain \\ ${ }^{2}$ Department of Geography and Geology, University of Copenhagen, Copenhagen, Denmark
}

Received 24 September 2010; $\quad$ revised 20 December 2010; $\quad$ accepted 25 February 2011; $\quad$ available online 1 March 2011

\begin{abstract}
The temperature depth profiles of six wells in the Motril-Salobren a aquifer were used as a basis for a comparative analysis involving various parameters to determine their relations and factors influencing the different trends. There is a clear influence of ambient temperature on all the profiles, with a lag time of two to five months. Nevertheless, there are clear differences in the temperature depth profile patterns that can be accounted for by other factors. First, there is a greater influence of localized recharge; Guadalfeo River as opposed to diffuse recharge; irrigation return flow and rainfall. Three of the wells located near the riverbed of the Guadalfeo River have extremely variable temperature-depth profiles and show clear river influence. In springtime, during the highest flood stages of the river due to cold melt water from the Sierra Nevada, the groundwater falls in temperature. During secondary peaks in river flow rates during the autumn due to rainfall, the warm water increases groundwater temperature. The effect of the river recharge decreases with distance from the course since there is less mixing with water from the Guadalfeo River. In addition, there are two temperature-depth profiles in which temperature variations remain shallow and follow a pattern that cannot be attributed to the influence of either of the above two parameters. Among these two cases, the most influential factor is the groundwater flow pattern typical of a discharge zone, characterized by vertical-flow components.
\end{abstract}

Keywords: Aquifer management; Diffuse recharge; Local recharge; River aquifer interaction; Vertical flow components

\section{INTRODUCTION}

The Motril-Salobreña detrital aquifer, on the Spanish Mediterranean coastline, is an extremely interesting research work since it is currently undergoing a series of changes that render it a natural laboratory that may help us to understand the workings of coastal aquifers in settings subject to considerable human influence. On one hand is a coastal zone that, until very recently, was self-sustainable in terms of the economy and the hydrological resources. The traditional crop was sugar cane, but it began to be replaced by more economically lucrative tropical fruit (cherimoya, avocado, and mango) irrigated primarily with water from the Guadalfeo River. The stability of this situation is reflected in the fact that, until a decade ago, the Motril-Salobreña aquifer maintained exceptional water quality and quantity on a sector in Mediterranean coast, in which $70 \%$ of coastal aquifers are affected to varying degrees by seawater intrusion (Calvache and Pulido-Bosch, 1991, 1994, 1996, 1997;

*Corresponding Author Email: calvache@ugr.es

Tel./ Fax: 34958244031
Gómez et al., 2003). In fact, the presence of several wetlands near the mouth of the Guadalfeo River and the artesian nature of several wells near the coastline confirmed the healthy status of this aquifer. This situation began to change at the start of this century with a series of circumstances such as the construction of a dam across the course of the Guadalfeo River, the substitution of traditional crops for greenhouses and the building of luxury subdivisions with gulf courses. All of these activities have had the effect of drastically reducing the recharge of the Motril-Salobreña aquifer. This human pressure, together with the effects of global climate change may lead to groundwater contamination (Longe and Enekwechi, 2007; Goyal et al., 2008; Ojuri and Ola, 2010), seawater intrusion (Praveena et al., 2010) or occurrence of aquifer overexploitation (Chenini and Khemiri, 2009).

The Rules dam was built only $17 \mathrm{~km}$ from the coast, upstream from the Motril-Salobreña aquifer and has been filling since May 2005 (Fig. 1). With a capacity of some $120 \mathrm{Mm}^{3}$ and a catchment of $1,070 \mathrm{~km}^{2}$, this 
reservoir is designed to make use of the flow of the Guadalfeo River and prevent loss of freshwater to the sea in an area where this resource is in short supply. The usefulness of the reservoir is clear, as it will provide a more continuous water supply to some population centres and will allow irrigated surface areas to be extended. On the other hand, it will have a negative effect on the Motril-Salobreña aquifer, as it will cut off or drastically reduce feed to the system. A lack of recharge can be extremely significant in a coastal aquifer due to the very great probability of marine intrusion.

However, in order to determine the extent of the effect of river recharge reduction on the aquifer, it is essential to quantify the river's role in the total water inflow to the aquifer. Several studies have attempted to find figures for this datum through numerical modelling or simply through the difference in the water budget (Castillo, 1975; Heredia et al., 2003; Ibáñez, 2005; Calvache et al., 2009; Duque, 2009), although there is still substantial disparity in the data provided. In this regard, variations in groundwater temperature due to inflow from the Guadalfeo River seem to be a useful research tool.
Temperature measurements are a typical parameter for use as tracers in the study of hydrological systems. Traditionally, this tool was applied mainly in environments with geothermal processes (Silliman and Robinson, 1989; Molina et al., 2002; Nagheeby and Kolahdoozan, 2010; Roshan et al., 2010). Nevertheless, improvements in data acquisition and simulation modelling (Constanz, 2008) have led to increased numbers of studies and applications of thermal measurements in recent years (Anderson, 2005; Imam and El baradei, 2009).

The thermal signal spread by rivers has been used for determining riverbed properties (Constanz, 1998), for quantifying stream water exchange with groundwater (Cox et al., 2007; Duque et al., 2009; Olsen and Young, 2009) for calculating the hydraulic properties of aquifers (Su et al., 2004) and the mean velocity of groundwater (Arai, 1993) or recharge characteristics (Taniguchi and Sharma, 1990, 1993) from different viewpoints such as process detection (Constanz and Thomas, 1997; Doppler et al., 2007), analytical solutions (Schmidt et al., 2007) and modelling
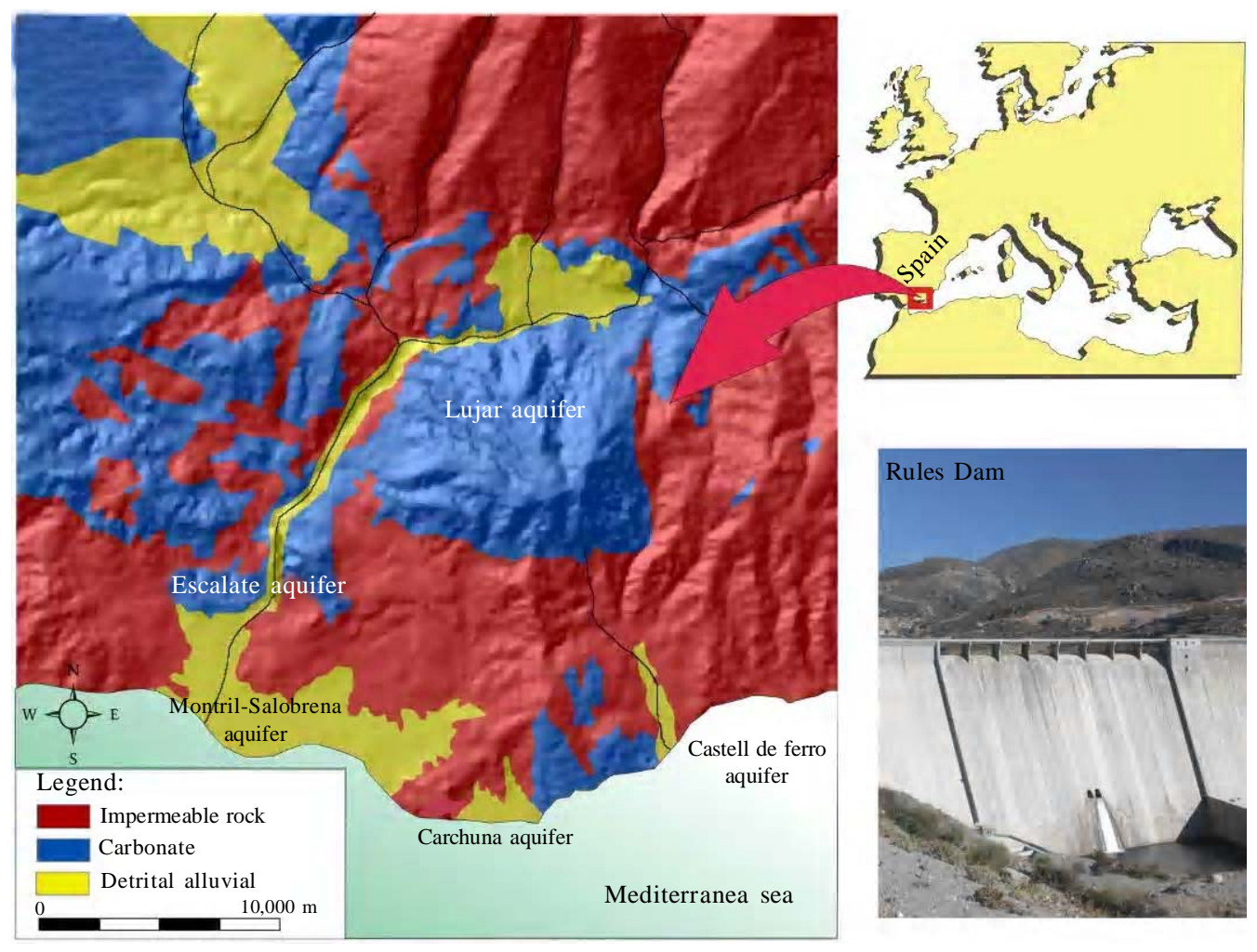

Fig. 1: Geological location of the Motril-Salobreña aquifer 
with different codes (Bundschuh, 1993; Burow et al., 2005; Healy, 2008). Another aspect of interest to researchers is using groundwater heat as a source for space heating and cooling (Lee and Hahn, 2006).

The main objective of this paper is to delineate the factors that influence the temperature profiles of groundwater in each of the sectors studied in the Motril-Salobreña aquifer. Thus, further studies may be undertaken using mathematical modeling to quantify the entry of water from each source identified from the relationship between the temperature of the recharge water and the ground water. This research will be basic for further specific quantification of the influence of one of the most important anthropogenic changes developed in this aquifer over the last decade.

\section{Hydrogeological setting}

The Motril-Salobreña aquifer covers a surface area of approximately $42 \mathrm{~km}^{2}$. It comprises the alluvial sediments supplied by the Guadalfeo River and its tributaries and other minor streams.

Geologically, the study area and its catchment basin form part of the Alpujárride Complex of the Internal Zones of the Betic Cordillera. This sector has metapelitic rocks, such as schists and phyllites (considered impermeable for practical purposes), as well as marbles (Aldaya, 1981); (Fig. 1). The carbonate outcrops comprise good aquifers and where they meet the alluvium, they provide hidden recharge to the detrital aquifer that is difficult to estimate. The alluvial rocks comprising the aquifer consist of alternating layers of gravel, sands, silts, and clays in varying proportions depending on the sector. The area farthest from the coastline, for instance, is dominated by fluvial sediments consisting of coarse channel and floodplain deposits. However, the largest sector of the aquifer, that closest to the coastline, is delta settings characterized by higher amounts of finer-grained sediments.

The Guadalfeo River cuts across the Motril-Salobreña aquifer north to south for about eight kilometres and supplies most of the system recharge. The river's catchment is mainly the southern slopes of the Sierra Nevada. Due to the elevations of the highest peaks (the Mulhacén is the highest on the Iberian Peninsula at 3,478 m), precipitation usually falls as snow throughout the rainy season in autumn and winter, and it does not melt until temperatures rise. Snowmelt tends to occur from March to July, coming either earlier or later depending on how warm and wet the year is.

The mixed rainfall-snowmelt supply of the Guadalfeo River produces an extremely uneven regime (Fig. 2). At times, for instance, the river can reach very high flow rates $\left(14 \mathrm{~m}^{3} / \mathrm{s}\right)$, whereas at others, generally in the summer, the flow can be much lower $\left(1 \mathrm{~m}^{3} / \mathrm{s}\right)$. Due to withdrawals for irrigation, the riverbed can often appear dry for several months of the year. On average, though, the flow rate is $6,600 \mathrm{~L} / \mathrm{s}$ for this region. The highest flow rates are usually recorded in springtime, when the Guadalfeo River carries mostly snowmelt, which is characteristically cold and poor in conductivity.

Autumn precipitation that is not snowmelt is noted as secondary peaks in the Guadalfeo River hydrographs. It does not cause the same flow rates as snowmelt and it also does not last as long. Moreover, it takes place during a period when requirements are lower.

The latest studies in the zone (Duque, 2009) show that the aquifer resources for an average year are at about $23 \mathrm{Mm}^{3} /$ year, divided into direct infiltration from the Guadalfeo River ( $21 \%$ of total input), irrigation return flows (39\%), direct rainfall infiltration (15\%) andhidden supplies from the Escalate aquifer and groundwater flow across the detrital formation that continues upvalley (25\%). This detrital formation is connected to the MotrilSalobreña aquifer, but it is not extensive as it lies in a narrow valley, thereby leading to an artificial boundary in this sector.

The Guadalfeo River is significant in the total recharge of the Motril-Salobreña aquifer not only due to direct infiltration from the riverbed, but also because of return from irrigation previously diverted from the river. Irrigation return flow in this region is also quite significant due to the use of the traditional technique of flooding, which uses much more water than required by the plants. This water then re-infiltrates to recharge the aquifer.

The aquifer discharge occurs primarily on the coastline boundary (74\%) since withdrawals comprise only $26 \%$ of total output in an average year.

For this study, the groundwater temperature profiles recorded at six control points since 2001 were used. The temperature profiles recorded after the entry into operation of the Rules dam (May 2005) have been dismissed. From this moment the Guadalfeoriver flow is almost zero (Fig. 2) and one of the main factors affecting the groundwater temperature is lost.

\section{MATERIALS AND METHODS}

Since November of 2001, monthly measurements have been made of groundwater electrical conductivity and temperature with a Relogger probe and $200 \mathrm{~m}$ of cable. Measurements are made at 


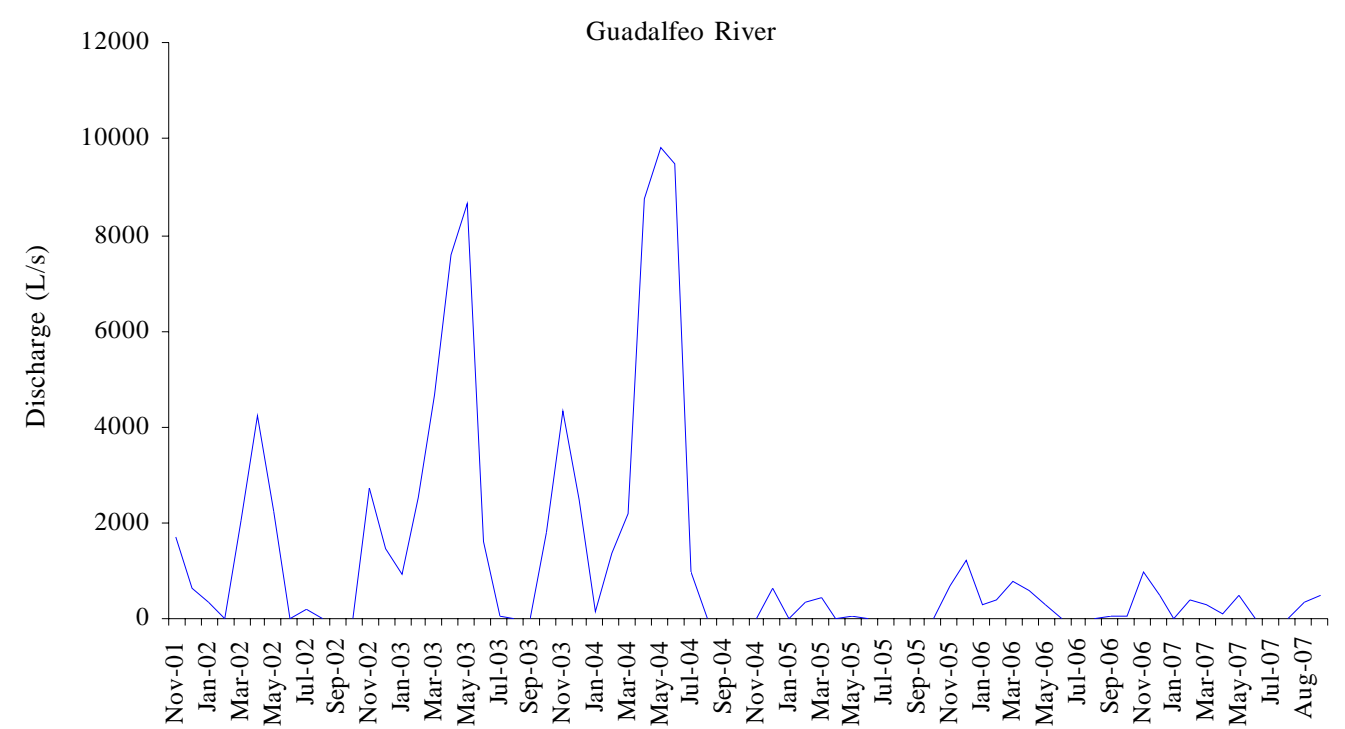

Fig. 2: Hydrograph of the Guadalfeo River. The flow-rate data refer to monthly averages

different depths at six distinct wells in the aquifer (Fig. 3) located near the current riverbed and in the aquifer zone with the highest transmissivity (Calvache et al., 2003). In most cases, the aquifer subtratum could not be reached, hence the data on the depth of the aquifer's impermeable substratum come from geophysical studies (Geirnaert et al.,1981; Soto, 1998; Duque et al., 2008). In the study zone, aquifer thickness ranges from $37 \mathrm{~m}$ at well 6 to over $250 \mathrm{~m}$ at the coastline.

It should be noted that the temperature measurements are always made at the same depths except for the shallowest, made when the water table is reached and therefore subject to change depending on the day of data collection. Moreover, due to its contact with the air, the temperature at this water surface is not a good indicator of the hydrogeology since it is heavily influenced by temperatures at the time of day the data is gathered. Therefore, the temperatures for the surface of the water are not shown on the graphs and have not been taken into account in the study. The shallowest data considered are consequently the second measurement (always at the same depth) and referred to as the subsurface temperatures (Fig. 3).

In order to determine the most influential factors affecting groundwater temperature, a comparative analysis was made with other parameters such as air temperature, water table, flow rate of the Guadalfeo River and distance from the riverbed. The air temperature was recorded at a weather station in the eastern zone of the Motril-Salobreña aquifer; the water table was measured monthly for the Motril-Salobreña aquifer with a probe. finally, the data for the Guadalfeo River flow rate covered several gauging stations.

\section{RESULTS AND DISCUSSION}

Temperature profiles

The temperature depth profiles at all the monitoring wells show an initial variable belt up to 15-45 m deep, where the temperature stabilizes and remains constant. Below that, it starts to rise due to the geothermal gradient at $100 \mathrm{~m}$ (only visible in \#14 as it is the only well deep enough). In the subsurface belt, the temperature is invariably either lower or higher than that found deeper for all points except well 13, where the temperature in the first $30 \mathrm{~m}$ for all the profiles done there is higher than in the rest of the column.

The temperature considered as constant for the groundwater changes throughout the aquifer, ranging between 17 and $18^{\circ} \mathrm{C}$. Changes in temperature in the upper zone range between 15 and $19^{\circ} \mathrm{C}$ in most cases, although it can reach up to $20^{\circ} \mathrm{C}$.

The temperature profiles logged for the different wells show a different trend. For instance, at well 13, the subsurface temperature ranges by only $1^{\circ} \mathrm{C}$ and in wells 14 and 16, the subsurface temperature shifts can reach $5^{\circ} \mathrm{C}$, although they only affect the first 15 $\mathrm{m}$ of depth. Finally, the profiles of wells 6,9 and 12 
Int. J. Environ. Sci. Tech., 8 (2), 223-236, Spring 2011
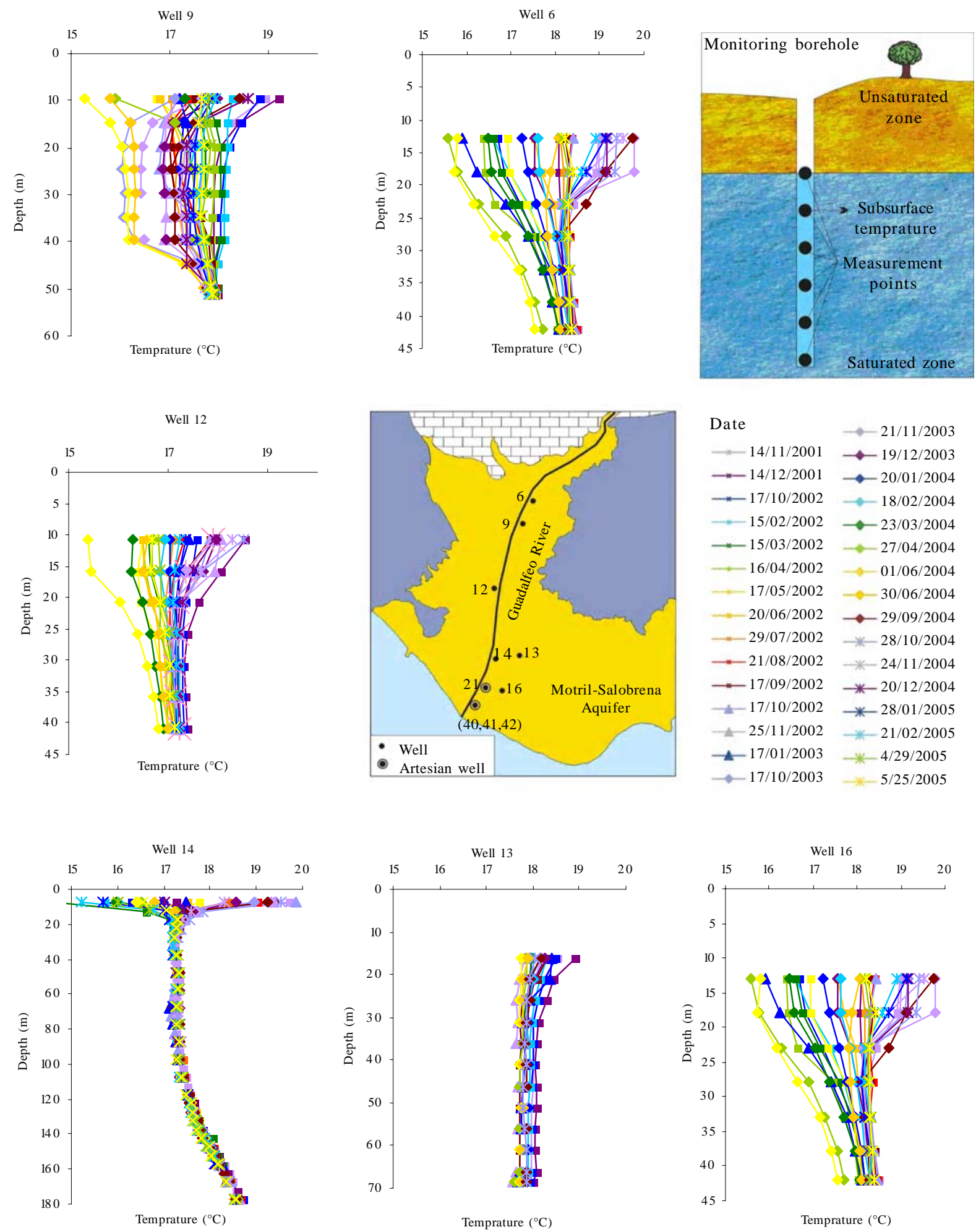

Fig. 3: Location and groundwater temperature profiles of wells analyzed 
show variations of up to $5{ }^{\circ} \mathrm{C}$ in the subsurface temperature, but the change is noted up to $45 \mathrm{~m}$ deep (Fig. 3).

The temperature variations in the subsurface section of the water column are likely due to the influence of both ambient temperature and of recharge water continually entering the aquifer. Since the sampling points are near the course of the Guadalfeo River, it is to be expected that any changes are strongly related to recharge from the colder or warmer waters of the river, particularly when river recharge is highest and the river has the highest flow rate.

Nevertheless, there must be other factors affecting temperature distribution in the groundwater that would account for the distinct trends found in the temperature profiles, which will be examine below.

\section{Groundwater temperature and ambient temperature}

The same graph has been used to show changes in both groundwater temperature logged at the six different depth points and in the monthly average ambient temperature recorded in Motril (Fig. 4). Specifically, the temperature recorded at two depths at the different wells was considered. The first is the subsurface temperature (Fig. 3), which ranges between 5 and $16 \mathrm{~m}$ deep and that records the greatest temperature variations (excluding the one closest to the surface). The second temperature measurement shown ranges between 30 and $40 \mathrm{~m}$ at the different wells. At this depth, temperature variations are very slight since any influence by external factors is buffered at these depths. In all cases, the water table is less than $10 \mathrm{~m}$ below the topographic surface (shallow wells according to the classification by Lee and Hahn, 2006, with some wells having an unsaturated zone only $0.7 \mathrm{~m}$ thick (well 16) and these show a periodic annual variation in groundwater temperatures. In fact, at most wells there is a periodic variation in groundwater temperature that is quite evident in the subsurface measurement. Only well 13 shows nearly imperceptible changes over time and at different depths. As mentioned above, the deepest logs (wells 6, 9 and 12) still show slight thermal changes, which does not occur at wells 14 and 16, where the record is flat for the entire period shown.

In order to establish the relation between temperature variations in the subsurface belt of the groundwater and changes in ambient temperature, the graphs of the average monthly temperature recorded at a weather station above the aquifer were examined.
There is a clear lag between the valleys and the peaks of the groundwater temperature and the ambient temperature. The ambient temperature lows occur from December to February, whereas the valleys for groundwater temperature occur from February to June. Similarly, the peaks for ambient temperature occur in July and August, whereas they almost always occur in November for the groundwater, although it can sometimes be in October or December.

The lag between the lows and the highs for the ambient and the groundwater temperatures ranges from two to five months for the lows and from two to four months for the highs, which is in agreement with the lags found by other authors (Arai, 1993; Lee and Hahn, 2006). Wells 14 and 16 always show a lag of three months for the lows and the highs, whereas wells 6,9 and 12 show more disparity. In well 6, for instance, there is a lag of two months for the lows, whereas well 9 has lags of up to five months for the lows.

As might be expected from the relative thinness of the saturated zone at wells 14 and 16 ( 3 and $0.7 \mathrm{~m}$, respectively), temperature changes are more abrupt at these points.Overall, ambient temperature is clearly a crucial factor in the groundwater temperature of the Motril-Salobreña aquifer, although significant differences amongst the wells still require clarification.

\section{Groundwater temperature and variations in the water table}

If the temperature variations are influenced by the aquifer recharge water, then there should be a relation between times of higher recharge and greater temperature variations in the groundwater. Since there are numerous recharge sources (the Guadalfeo River, irrigation return flow, rainfall and hidden supplies at the northern boundary), the water table shall be considered as a parameter directly related to recharge. In addition, whether there is a relation between the two parameters and whether it is possible to establish differences in the influences brought to bear by distinct recharge sources, shall be confirmed.

The evolution of the water table in the various wells is shown in order to establish this relation (Fig. 4). In fact, some wells clearly show an inverse relation between the two parameters, with the water-table peaks coinciding in time with the temperature lows of the subsurface belt of groundwater. This effect is plain to see in wells 6,9 , and 12 , but cannot be 
established in wells 13,14 or 16 . This initial observation would seem to imply that not all the recharge sources have an easily recognizable influence on groundwater temperature. The wells near the course of the Guadalfeo River (6, 9 and 12), where the recharge source most influencing the water table is the river itself, have a clear temperature-water table relation. For wells 13 and 16, about $500 \mathrm{~m}$ from the current course of the Guadalfeo River and where the water table can therefore be a reflection of recharge sources other than the river, irrigation return flow and rainfall, the lack of correspondence between temperature and water table indicates that the diffuse aquifer recharge has less influence on the groundwater temperature, or at least, it is less obvious than the river's effect. The data for well 14 are more complicated since it is near the riverbed and therefore the river recharge influence is highest, but the temperature low values do not coincide with water table peaks. This case will be treated in more details in following sections.There is also coincidence between the temperature peaks in groundwater and the secondary peaks of the water table in wells 6, 9 and 12 . This scenario is once again accounted for by the dominant influence of river recharge during the autumn in the latter. Autumn rains
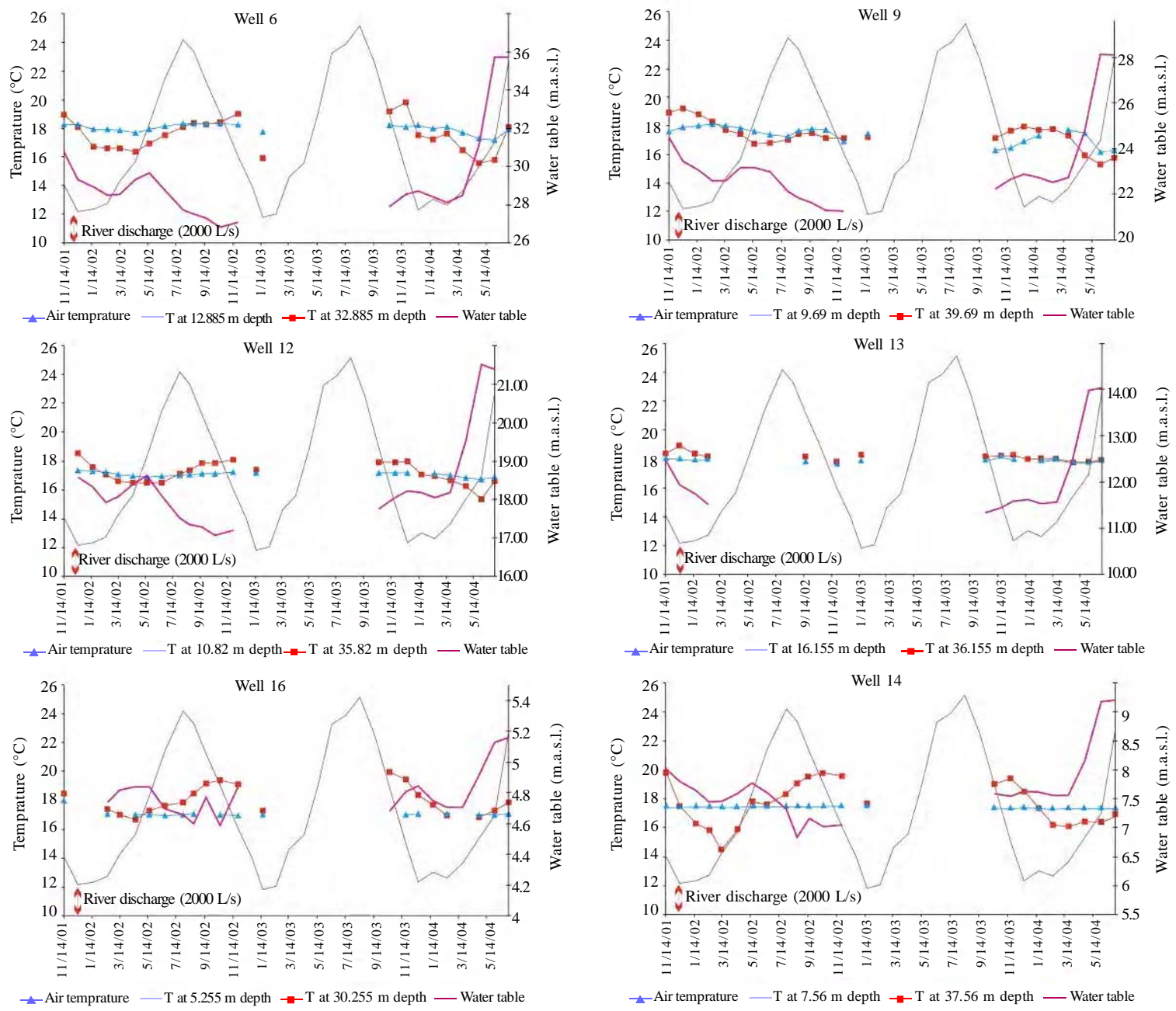

Fig. 4: The water table, air temperature, groundwater temperature at two different depths, and Guadalfeo River discharge at the six wells analyzed 
cause warmer temperatures in the river water and lower flow rates than those in the springtime due to snowmelt. Therefore, the effect of these rains on the aquifer is lesser and similar to that of the ambient temperature.

Analysis indicates that localized recharge sources (Guadalfeo River) affect groundwater temperature more than diffuse recharge sources (e.g., irrigation return flow or rainfall). Even though these diffuse recharges amount to double (54\%) that of the sporadic recharge from the Guadalfeo River (21\%), the influence of the latter on groundwater temperature is much more evident.

\section{Effect of the Guadalfeo River flow rate}

The hydrograph of the Guadalfeo River shows a large difference between flow rates prior to and after 2004 (Fig. 2). The first part shows significant peaks of up to $10 \mathrm{~m}^{3} / \mathrm{s}$, whereas, in contrast, the second part shows much lower flow rates reaching peaks of only 1 $\mathrm{m}^{3} / \mathrm{s}$. This abrupt shift is due to the coming online of the rules dam, which controls the flow of the Guadalfeo River, preventing significant volumes of water from reaching as far as the Motril-Salobreña aquifer. Flows reaching that part of the river derive primarily from surface runoff from the catchment basin downstream of the dam and from groundwater discharges from the Sierra de Lújar carbonate aquifer, also downstream of the dam. This section analyses the temperature profiles logged in the period prior to the filling of the dam since there were higher flow rates then, therefore, its influence on the groundwater must have been more evident.

There are five flood periods in the river that stand out for the period: the springs of 2002, 2003 and 2004; and the autumns of 2002 and 2003. For these events, only the data for groundwater temperature from the springs of 2002 and 2004, the autumn of 2002 and a single month of the autumn of 2003 are availavle. As it can be seen in Fig. 4, the variations in groundwater temperature at wells 6, 9 and 12 are related to peak flow rates in the Guadalfeo River. In order to establish the exact influence and whether there is any difference between recharge events with melt waters (colder) in spring and rainfall water (warmer), the temperature profiles are separated into events for springtime, autumn and the summer, when the riverbed is dry and therefore its influence should be nil (Fig. 5). The three sections of the figure show the same trend in the temperature profiles for the springs of 2002 and 2004, with the temperature rising with depth. The temperatures in these profiles fall as low as $15^{\circ} \mathrm{C}$, in contrast with the $17-18{ }^{\circ} \mathrm{C}$ average temperature of groundwater in the aquifer. If each spring event is taken separately, it can be seen that, starting in February, the temperature profiles log gradually lower temperatures until the point (May 2002 and June 2004) where this trend reverses and temperatures begin to rise. This effect indicates that the river water, despite being melt water, is warmed by the high ambient temperatures in those months. During the autumns of 2001, 2003 and 2004, in which the river also has relative flow-rate peaks due, in this case, to rainfall, the temperature profiles also have a characteristic trend opposite to the previous one. The groundwater temperature can reach nearly $20{ }^{\circ} \mathrm{C}$ in the subsurface zone, but drops as the water deepens. January and February of 2005 are special cases that show warm-water profiles instead of coldwater ones as in the same months in other years. In the hydrological year of 2004-2005, snowfall was scarce and there was therefore little snowmelt to lower the groundwater temperatures.

Finally, there are the summer profiles, which show no changes in temperature since there is no recharge from the Guadalfeo River. Again, April and May of 2005 are noteworthy as they would normally show considerable influence from cold melt waters. However, due to the afore-mentioned drought and the coming online of the Rules dam, there is no effect noted on the groundwater. Comprehensively quantify the degree of influence of the Guadalfeo River on the groundwater temperature is very difficult because the condition occurs in opposite directions depending on the time of the year in question. For example, during the winterspring (and only during the first months of spring) the groundwater temperature drops as the flow increases; however, during the autumn groundwater temperature increases as the flow increases. For this reason, the correlation between the two parameters by focusing only on the high flow episodes (winterspring) have been analyzed. Fig. 6 shows in some places an inverse relationship between temperature and flow. The clearest example is found in the well 9 where it gets a $\mathrm{R}^{2}$ value of 0.70 , indicating a high correlation between both parameters. In fact, it could set the temperature change could cause the recharge from the Guadalfeo River knowing its flow according to the relationship:

Flow = -258,64 Groundwater Temperature + 4718,7 


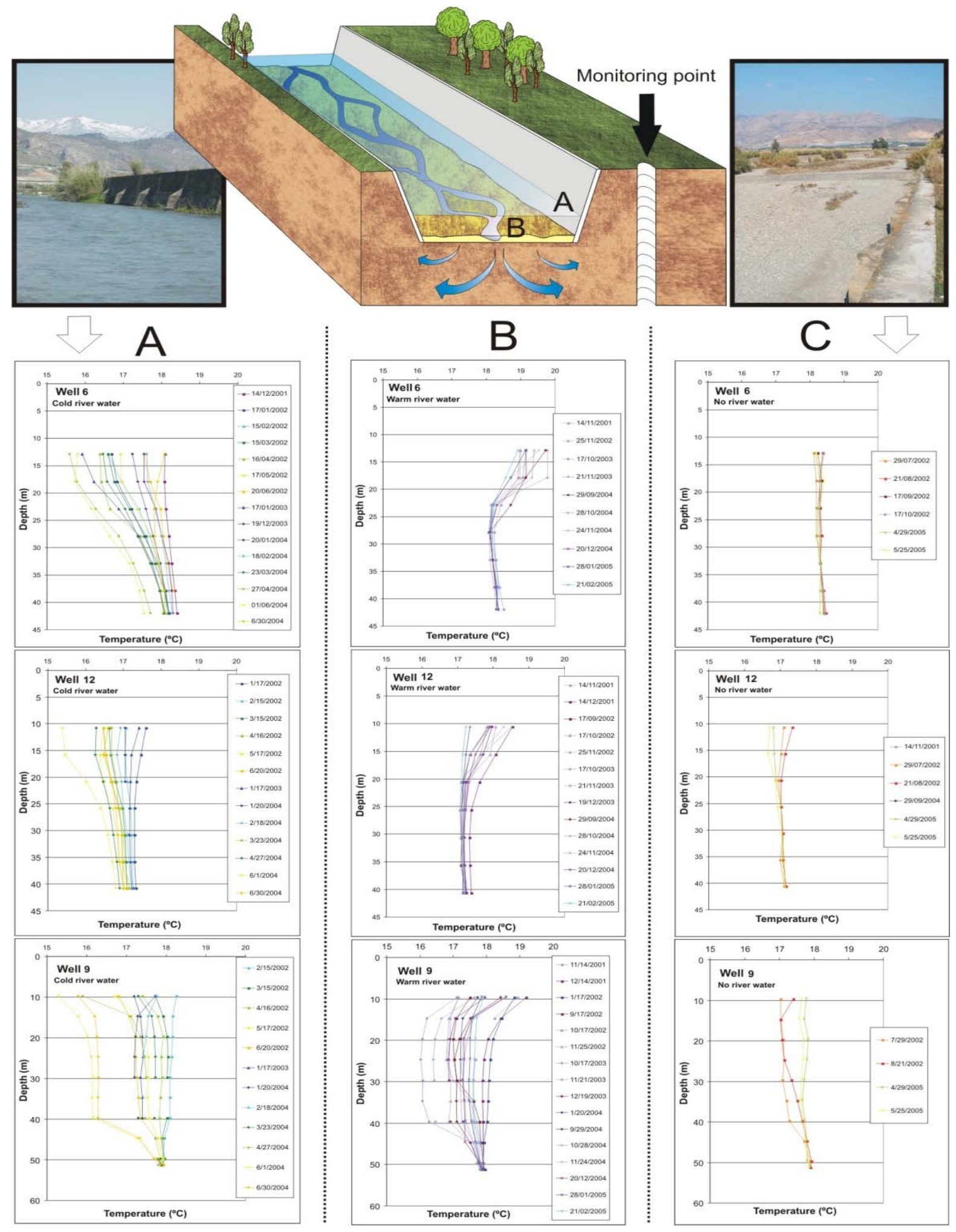

Fig. 5: Groundwater temperature profiles for three aquifer wells for springtime, summertime and autumn 
An interesting case is the well 13, where initially in Fig. 4 the relationship is not observed because of the small variation in temperature. On the contrary, in Fig. 6 the relationship between both parameters can be establish, though with less correlation than in the case of well 9.

\section{Effect of proximity to the riverbed}

There is a clear influence of the Guadalfeo River on groundwater temperature, particularly when the river flow rate is high. Whether this influence varies according to distance from the riverbed, should be examined. To do so, three wells were chosen with different distances from the coastline but along the same transverse line from the riverbed (Fig. 7). Well 6 is $10 \mathrm{~m}$ from the riverbed, well 12 is $60 \mathrm{~m}$ from it and well 13 is $400 \mathrm{~m}$ from it. As it can be seen, the trend of the temperature profiles varies according to proximity to the riverbed. The wells closer to the river show greater temperature variations (the largest variation in well 6 is $4.2^{\circ} \mathrm{C}$ and in well 12 it is $3.2^{\circ} \mathrm{C}$ ), whereas the farthest well from the riverbed shows much lower variations (well 13, maximum variation $1^{\circ} \mathrm{C}$ ). In the well farthest from the Guadalfeo River (13), the temperature profiles are very similar for any time of year. At well 6, there is a clear dependence between season and the resulting
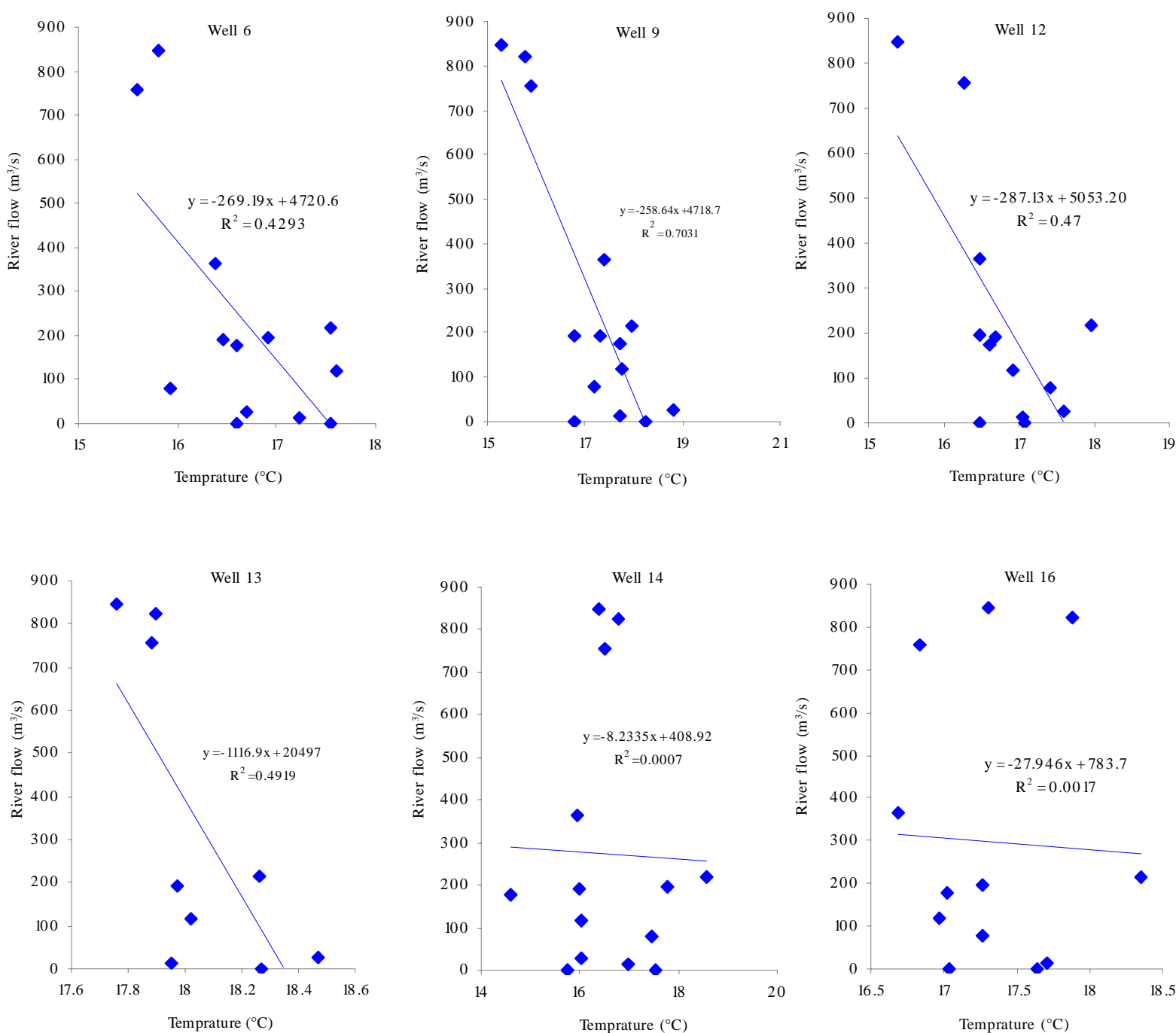

Fig. 6: Relationship between Guadalfeo River flow $\left(\mathrm{m}^{3} / \mathrm{s}\right)$ and groundwater temperature $\left({ }^{\circ} \mathrm{C}\right)$ to the moments of greatest flow (Winter-Spring) 

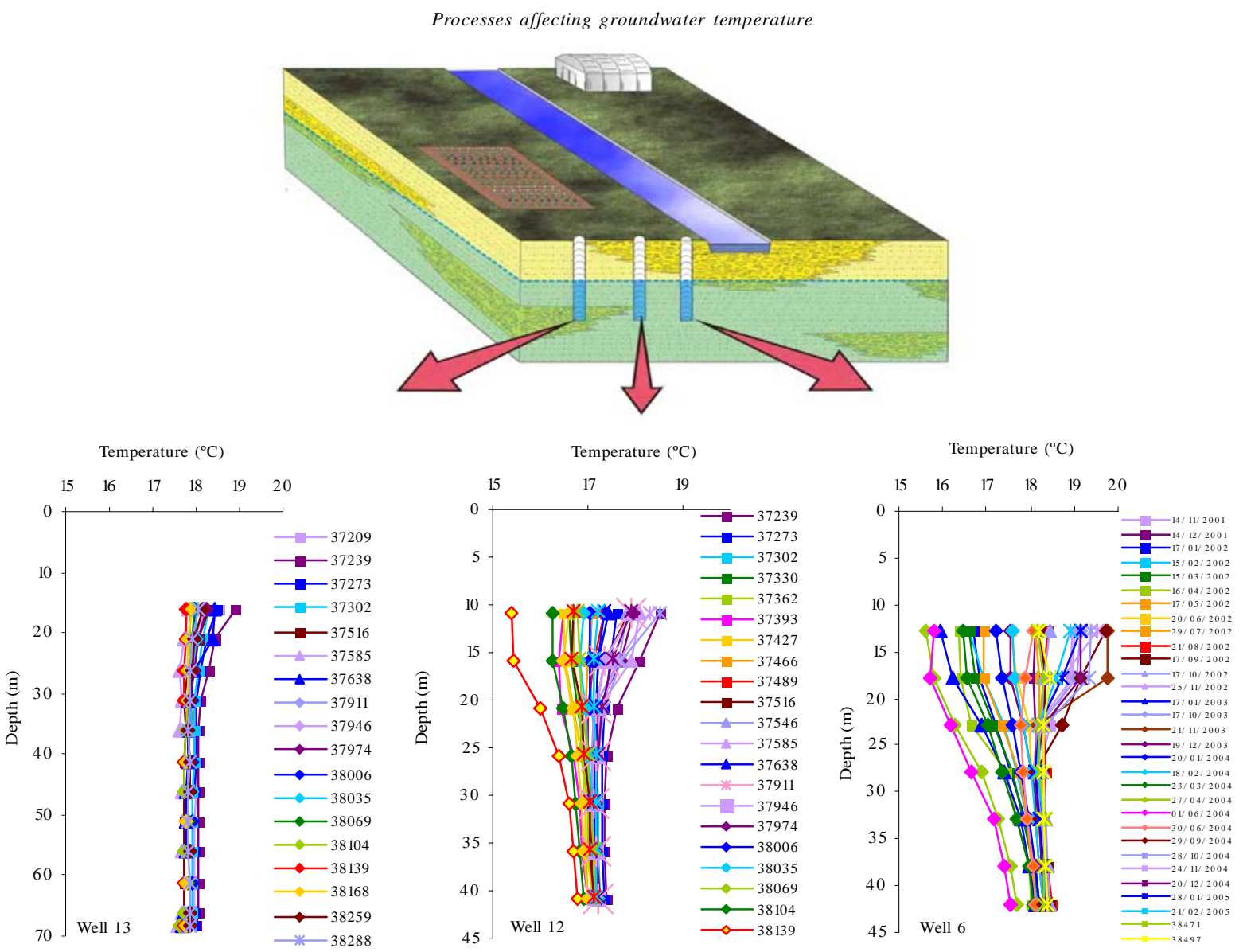

Fig. 7: Influence of distance to the Guadalfeo River in the temperature-profile patterns for three of the wells. Well 6 is $10 \mathrm{~m}$ away, well 12 is $60 \mathrm{~m}$ away, and well 13 is $400 \mathrm{~m}$ away from the riverbed

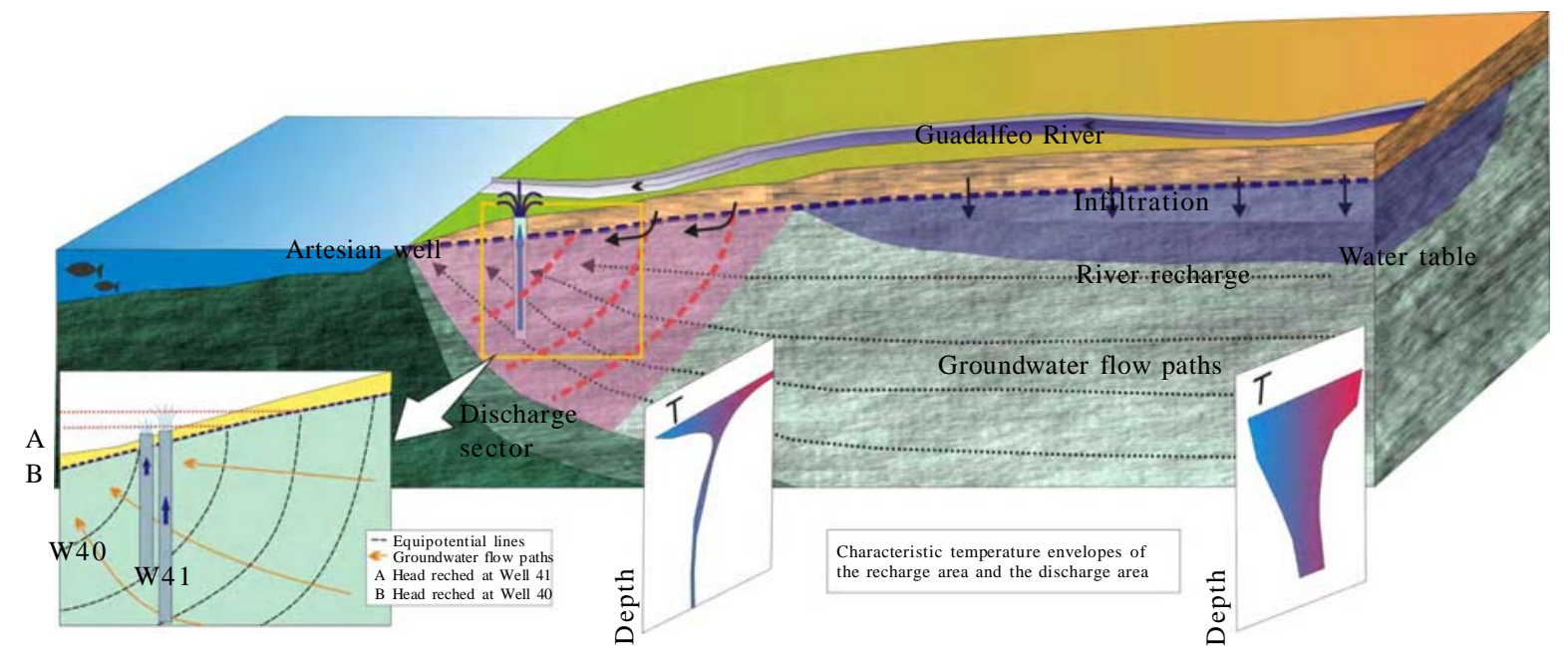

Fig. 8: Discharge flow pattern of the Motril-Salobreña aquifer in the freshwater-saltwater contact zone. Explanation for the artesian wells 40 and 41 , located $300 \mathrm{~m}$ from the coastline 
temperature profile. Since proximity to the riverbed is the biggest difference between the two points, it is deduced that distance to the river controls the contrast between the temperature profiles. Temperature data are far more scattered in wells closer to the riverbed than in those several hundred metres away. The water of the Guadalfeo River infiltrates the aquifer and mixes with the existing groundwater, altering its temperature. This thermal plume mixes with the groundwater and travels in the main direction of groundwater flow (N-S) and at right angles to it (E$\mathrm{W})$. In the zone closest to the river, influence is greatest, then it gradually decreases with distance from the riverbed until it is finally nil.

\section{Effect of groundwater flow pattern}

The temperature profiles for wells 14 and 16 show a different trend for which no clear relation was found with any of the factors analysed in this work. The profiles have an initial narrow subsurface belt (only $15 \mathrm{~m}$ deep) that varies up to $5^{\circ} \mathrm{C}$ in temperature (Fig. 3). From $15 \mathrm{~m}$ on down, the temperature is invariable all year round, coinciding in all the different wells. This type of temperature profile has been attributed to gaining streams in studies on river-aquifer relations (Taniguchi and Sharma, 1990; 1993). In the case of well 14, however, this interpretation is not applicable because the water table does not reach the level of the riverbed; consequently, there can be no discharge. As for well 16, it is not feasible because it is located $300 \mathrm{~m}$ from the riverbed. In Fig. 4, it can be noted that the groundwater temperature in these two wells varies similarly over time and that the variations echo the ambient temperature with a lag time of about three months. The groundwater temperature in this subsurface belt seems to be influenced only by ambient temperature. Fig. 4 also shows no clear relation between the water table or flow rate of the river and the temperature evolutions of wells 14 and 16 despite the fact that well 14 is only $7 \mathrm{~m}$ from the riverbed. It is worth noting once more the curious fact that these two wells have such similar trends despite being so far from one another $(1,200 \mathrm{~m})$ and with one close to the riverbed (14) and the other 300 $\mathrm{m}$ away from it. No less curious is the difference between the temperature profiles at well 13, which is also quite far from the Guadalfeo River (400 m compared to the $300 \mathrm{~m}$ of well 16), although in this case much farther from the coastline $(2.5 \mathrm{~km})$. The most unusual circumstances needing to be accounted for are probably the shallowness of the annual temperature variations $(15 \mathrm{~m}$ ) and the fact that well 14 , next to the riverbed, does not seem to be affected by any recharge from the river. The explanation is likely found in the groundwater flow pattern in this area of the aquifer. In the sector near the mouth of the Guadalfeo River there is a series of artesian wells. At $300 \mathrm{~m}$ from the coastline, there are three wells clustered within a few metres of each other. They vary in depth however, reaching $250 \mathrm{~m}, 135 \mathrm{~m}$ and $45 \mathrm{~m}$ deep, with water tables of $3,2 \mathrm{~m}, 2,5 \mathrm{~m}$ and $1.5 \mathrm{~m}$ above the surrounding land, respectively (the wells were built very recently and have not yet be topographically levelled). $600 \mathrm{~m}$ from the coastline is yet another artesian well (\#21). Another noteworthy feature is that the last section of the Guadalfeo River receives discharge from the aquifer and, before the Rules dam came online, there was a series of wetlands next to the coast. All these factors seem to indicate a flow pattern typical of discharge zones, with features of vertical flow and increasing head with depth, which would account for the distinct water tables evident at the three wells mere metres from one another but with different depths. This discharge-zone flow pattern, typical of the freshwater-saltwater contact in a coastal aquifer (Glover, 1959) is even more pronounced due to the fact that the Motril-Salobreña aquifer has quite a high horizontal hydraulic gradient, which in turn causes an equally large vertical hydraulic gradient in the discharge zone (Fig. 8).

Wells 14 and 16, both near the coastline, show no artesian features, but must nonetheless be affected by vertical-flow components. In fact, when well 16 (55 m deep) is at its highest levels, the water table coincides with the topographic surface, thus the surrounding land should be flooded. However, that does not actually happen. These vertical-flow components are what prevent the mixture of surface water, from river recharge or from any type of diffuse recharge, with groundwater. Therefore, in this case, the groundwater temperature variations must be due exclusively to the influence of ambient temperature.

\section{CONCLUSION}

The temperature profiles logged in six wells of the Motril-Salobreña aquifer show a shallow belt of variable temperature (up to $5{ }^{\circ} \mathrm{C}$ ) that can reach depths in the groundwater ranging from $15 \mathrm{~m}$ to $45 \mathrm{~m}$. Periodic changes 
in the subsurface belt are related with ambient temperature variations with lag times of two to five months for the lows and two to four months for the peaks. The relation between the groundwater temperature variations and the water table indicate a greater influence of localized recharge sources (Guadalfeo River) compared to diffuse recharge sources (irrigation return flow and rainfall). There is a clear influence of the river reflected in a decrease in temperature coinciding with peak flow rates in the river and the highest water tables in the aquifer during the springtime when the river flow derives mainly from snowmelt from Sierra Nevada. In the autumn, there are secondary peaks in river flow rates due to rainfall and the river temperature is higher than in spring. In this case, the groundwater temperature rises. This influence fades with distance from the river. Wells 14 and 16 are exceptions, however, as there is no clear coincidence between temperature valleys and peaks in the river flow rate and water table, making it difficult to establish a relation between the groundwater temperatures and the river recharge in these two cases. Instead, a groundwater flow pattern typical of freshwater-saltwater contact zones evident in vertical flows that hinder the mixing of water from surface recharge with existing groundwater must be recurred to. Groundwater temperature is therefore not only an excellent marker for determining the main zones and recharge times in an aquifer, but also it is useful in establishing distinct patterns in groundwater flow.

\section{ACKNOWLEDGEMENTS}

This research financed by Project CGL2008-05016; Ministry of Science and Innovation and by the Research Group Sedimentary Geology and Groundwater (RNM-369) of the Junta de Andalucía. Christine Laurin is thanked for the English version of the text.

\section{REFERENCES}

Aldaya, F., (1981). Sheet 1056 (Albuñol) of the geological map of Spain, scale 1:50000. Ed. IGME: Madrid.

Anderson, M. P., (2005). Heat as a ground water tracer. Ground Water, 43 (6), 951-968 (18 pages)

Arai, T., (1993). Estimation of groundwater-flow from temperature distribution, in: Tracers in Hydrology, IAHS Publication $\mathrm{N}^{\circ} 215$, 101-107 (7 pages).

Bundschuh, J., (1993). Modeling annual variations of spring and groundwater temperatures associated with shallow aquifer systems. J. Hydrol., 142, 427-444 (18 pages).

Burow, K. R.; Constanz, J.; Fujii, R., (2005). Using heat as a tracer to estimate dissolved organic carbon flux beneath a restored wetland. Ground Wat., 43 (4), 545-556 (12 pages).

Calvache, M. L.; Ibáñez, S.; Duque, C.; Martín Rosales, W.; López Chicano, M.; Rubio, J. C.; González, A.; Viseras, C., (2009). Numerical modelling of the potential effects of a dam on a coastal aquifer in southern Spain. Hydrol. Process., 23, 1268-1281 (18 Pages).

Calvache, M. L.; Pulido-Bosch, A., (1991). Saltwater intrusion into a small coastal aquifer (Rio Verde, Almuñecar, southern Spain). J. Hydrol., 129 (1-4), 195-213 (19 Pages)

Calvache, M. L.; Pulido-Bosch, A., (1994). Modelling the effects of salt water intrusion dynamics for coastal karstified block connected to a detrital aquifer. Ground Water, 32 (5), 767-777 (11 pages).

Calvache, M. L.; Pulido-Bosch, A., (1996). Processus d'intrusionextrusion marine dans des aquifères côtiers du sud de l'Espagne., C. R. Sci. Paris; Geosci., 323, 673-679 (7 pages).

Calvache, M. L.; Pulido-Bosch, A., (1997). Effects of geology and human activity on the dynamics of salt-water intrusion in three coastal aquifers in southern Spain. Environ. Geol., 30, 215-223 (9 pages).

Calvache, M. L.; Rubio, J. C.; López-Chicano, M; González-Ramón, A.; Ibáñez, S.; Martín-Rosales, W.; Soler, R.; Díaz-Losada, E., (2003). Estado actual del acuífero costero de Motril-Salobreña previo a la puesta en funcionamiento de la presa de Rules [Current state of Motril-Salobreña coastal Aquifer prior to operation of the Rules Dam], in: Proceedings of Coastal Aquifers Intrusion Technology: Mediterranean Countries, Alicante.

Castillo, E., (1975). Hidrogeología de la Vega de Motril-Salobreña y sus bordes [Hydrogeology of the Vega de Motril-Salobreña and its edges]., M.Sc. thesis, University of Granada, Granada.

Chenini, I.; Khemiri, S., (2009). Evaluation of ground water quality using multiple linear regression and structural equation modeling. Int. J. Environ. Sci. Tech., 6 (3), 509-519 (11 pages).

Constantz, J., (1998). Interaction between stream temperature, streamflow, and groundwater exchanges in alpine streams., Water Resour. Res., 34 (7), 1609-1615 (7 pages).

Constantz J., (2008). Heat as a tracer to determine streambed water exchanges. Water Resour. Res., 44, W00D10.

Constantz, J.; Thomas, L. T., (1997). Stream bed temperature profiles as indicators of percolation characteristics beneath arroyos in the middle Rio Grande Basin, USA. Hydrol. Process, 11, 1621-1634 (14 pages).

Cox, M. H.; Su, G. W.; Constantz. J., (2007). Heat, chloride, and specific conductance as ground water tracers near streams. Ground Water, 45 (2), 187-195 (9 pages).

Doppler, T.; Hendricks Franssen, H.; Kaiser, H.; Kuhlmann, U.; Stauffer, F., (2007). Field evidence of a dynamic leakage coefficient for modeling river-aquifer interactions. J. Hydrol., 347 (1-2), 177-187 (11 pages).

Duque, C., (2009). Influencia antrópica sobre la hidrogeología del acuífero Motril-Salobreña [Anthropogenic influence on the hydrogeology of the Motril-Salobreña Aquifer], Ph.D Thesis, University of Granada, Granada.

Duque, C.; Calvache, M. L.; Engesgaard, P., (2009). Investigating river-aquifer relations using water temperature in an anthropized environment (Motril-Salobreña aquifer). J. Hydrol., 381 (1-2), 121-133 (13 pages).

Duque, C.; Calvache, M. L.; Pedrera, A.; Martín-Rosales, W.; LópezChicano, M., (2008). Combined time domain electromagnetic soundings and gravimetry to determine marine intrusion in a detrital coastal aquifer (southern Spain). J. Hydrol., 349 (3-4), 536-547 (12 pages).

Geirnaert, W.; Pulido-Bosch, A.; Castillo, E.; Ferández-Rubio, R., (1981). Estudio de la geometría del acuífero detrítico de la vega de Motril-Salobreña mediante SEV [Geometry study of the detrital aquifer in the Motril-Salobreña plain via VES], in: Proceedings of $1^{\text {st }}$ Simposio del Agua en Andalucía. 291-302 (13 pages). 
Glover, R. E., (1959). The pattern of fresh-water flow in a coastal aquifer. J. Geoph. Res., 64 (4), 457-459 (3 pages).

Gómez, J. D.; López, J. A.; Garrido, E., (2003). The state of seawater intrusion in Spain, in: López-Geta, J. A., Gómez, J. D., de la Orden, J. A., Ramos, G., Rodríguez, L. (Eds.), Coastal Aquifers Intrusion Technology: Mediterranean Countries, Ed. IGME, Madrid, 169-186 (18 pages).

Goyal, P.; Sharma, P.; Srivastava, S.; Srivastava, M. M., (2008). Saraca indica leaf powder for decontamination of $\mathrm{Pb}$ : removal, recovery, adsorbent characterization and equilibrium modeling. Int. J. Environ. Sci. Tech., 5 (1), 2734 (8 pages).

Healy, R. W., (2008). Simulating water, solute, and heat transport in the subsurface with the VS2DI software package. Vadose Zone J., 7 (2), 632-639 (8 pages).

Healy, R.W.; and Ronan, A.D., (1996). Documentation of computer program VS2DH for simulation of energy transport in variably saturated porous media modification of the U.S. Geological Survey's computer program VS2DT: U.S. Geological Survey Water Resources Investigations Report 964230, 36 p.

Heredia, J.; Murillo, J. M.; García-Arostegui, J. L.; Rubio, J. C.; Lopez-Geta, J. A., (2003). Influencia antrópica en un acuífero costero. Consideraciones sobre la gestión hídrica del acuífero de Motril-Salobreña (España) [Anthropogenic influence on a coastal aquifer. Considerations on the hydraulic management of the Motril-Salobreña aquifer]., Rev. Latino-Amer. Hidrogeol., 3, 73-83 (11 pages).

Ibáñez, S., (2005). Comparación de la aplicación de distintos modelos matemáticos sobre acuíferos costeros detríticos [Comparison of the application of different mathematical models of detrital coastal aquifer]., Ph.D. Thesis, University of Granada, Granada.

Imam, E. H.; El Baradei, S. A., (2009). Impact of control structures on assimilative capacity of rivers and fish habitat. Int. J. Environ. Sci. Tech., 6 (2), 315-324 (10 pages).

Lee, J. Y.; Hahn, J. S., (2006). Characterization of groundwater temperature obtained from the Korean national groundwater monitoring stations: Implications for heat pumps. J. Hydrol., 329 (3-4), 514-526 (13 pages).

Longe, E. O.; Enekwechi, L. O., (2007). Investigation on potential groundwater impacts and influence of local hydrogeology on natural attenuation of leachate at a municipal landfill. Int. J. Environ. Sci. Tech., 4 (1), 133-140 (8 pages).

Molina, L.; Vallejos, A.; Pulido-Bosch, A.; Sánchez-Martos, F., (2002). Water temperature and conductivity variability as indicators of groundwater behavior in complex aquifer systems in the south-east of Spain. Hydrol. Process., 16, 33653378 (14 pages).

Nagheeby, M.; Kolahdoozan, M., (2010). Numerical modeling of two-phase fluid flow and oil slick transport in estuarine water. Int. J. Environ. Sci. Tech., 7 (4), 771-784 (14 pages).

Ojuri, O.; Ola, S. A., (2010). Estimation of contaminant transport parameters for a tropical sand in a sand tank model. Int. J. Environ. Sci. Tech., 7 (2), 385-394 (10 pages).

Olsen, D. A.; Young, R. G., (2009). Significance of river-aquifer interactions for reach-scale thermal patterns and trout growth potential in the Motueka River, New Zeland., Hydrogeol. J., 17 (1), 175-183 (13 pages).

Praveena, S. M.; Aris, A. Z., (2010). Groundwater resources assessment using numerical model: A case study in low-lying coastal area. Int. J. Environ. Sci. Tech., 7 (1), 135-146 (11 pages).

Pulido-Bosch, A.; Rubio, J. C., (1988). Los acuíferos costeros de Motril-Salobreña [The coastal aquifers of MotrilSalobreña], in: TIAC’88. Almuñécar, Spain, 209-238 (30 pages).

Roshan, G. R.; Ranjbar, F.; Orosa, J. A., (2010). Simulation of global warming effect on outdoor thermal comfort conditions. Int. J. Environ. Sci. Tech., 7 (3), 571-580 (10 pages).

Schmidt, C.; Conant, Jr. B.; Bayer-Raich, M.; Schirmer, M., (2007). Evaluation and field-scale application of an analytical method to quantify groundwater discharge using mapped streambed temperatures. J. Hydrol., 347 (3-4), 292307 (16 pages)

Silliman, S. E.; Robinson, R., (1989). Identifying fracture interconnections between boreholes using natural temperature profiling: I. Conceptual basis., Ground Water, 27 (3), 393-402 (10 pages).

Soto, J. M., (1998). Aportaciones al conocimiento del acuífero detrítico de Motril-Salobreña (Granada) [Contributions to the knowledge of Motril-Salobreña detrital Aquifer (Granada)]., M.Sc. thesis, University of Granada, Granada.

Su, G. W.; Jasperse, J.; Seymour. D.; Constante, J., (2004). Estimation of hydraulic conductivity in an alluvial system using temperatures., Ground Water, 42 (6), 890-901 (12 pages).

Taniguchi, M.; Sharma M. L., (1990). Solute and heat transport experiments for estimating recharge rate. J. Hydrol., 119, 57-69 (13 pages).

Taniguchi, M.; Sharma M. L., (1993). Determination of groundwater recharge using the change in soil temperature. J. Hydrol., 148, 219-229 (11 pages).

\footnotetext{
AUTHOR (S) BIOSKETCHES

Calvache M. L., Ph.D., Department of Geodynamics and Research Planning, Secretariat in the University of Granada, Avda. Fuentenueva, 18071 Granada, Spain. E-mail: calvache@ugr.es

Duque, C., Ph.D., Department of Geology, University of Copenhagen, Copenhagen, Denmark. E-mail: cduque@ugr.es

Gomez Fontalva, J. M., Ph.D., Department of Geodynamics and Research Planning, University of Granada, Avda. Fuentenueva, 18071 Granada, Spain. E-mail: chemagomez@ugr.es

Crespo, F., B.Sc., Research student in Hydrogeology at the University of Granada, Avda. Fuentenueva, 18071 Granada, Spain. E-mail: fcrespo@correo.ugr.es
}

Calvache M. L.; Duque, C.; Gomez Fontalva, J. M.; Crespo, F., (2011). Processes affecting groundwater temperature patterns in a coastal aquifer. Int. J. Environ. Sci. Tech., 8 (2), 223-236. 